\title{
Curromycin A as a GRP78 downregulator and a new cyclic dipeptide from Streptomyces sp.
}

\author{
Yoichi Hayakawa $^{1}$, Minami Akimoto ${ }^{1}$, Akari Ishikawa ${ }^{1}$, Masumi Izawa ${ }^{1}$ and Kazuo Shin-ya ${ }^{2}$ \\ The Journal of Antibiotics (2016) 69, 187-188; doi:10.1038/ja.2015.115; published online 25 November 2015
}

Solid cancers are often nutrient-starved because of poor blood circulation and such tumor cells show remarkable tolerance to nutrient deprivation. ${ }^{1}$ Thus, antitumor substances targeting resistance to nutrient deprivation may show selective activity against solid cancer cells. In the course of a screening for selective cytotoxic compounds under nutrient-deprived conditions, an actinomycete strain RAI364 was found to produce an active substance. Strain RAI364 was identified as a member of the genus Streptomyces based on the $16 \mathrm{~S}$ rRNA sequence, ${ }^{2}$ which revealed high identity with those of Streptomyces cuspidosporus NBRC 12378 (99.3\%), Streptomyces cuspidosporus NBRC 12379 (99.3\%) and Streptomyces ribosidificus NBRC 13796 (99.3\%).

The producing organism was cultivated in 500-ml Erlenmeyer flasks containing $100 \mathrm{ml}$ of a medium consisting of $2.5 \%$ glucose, $1.5 \%$ soybean meal (Nisshin Oillio Group, Tokyo, Japan), $0.2 \%$ dry yeast (Asahi Food \& Healthcare, Tokyo, Japan) and $0.4 \%$ calcium carbonate (pH 6.2, before autoclave) on a rotary shaker at $27^{\circ} \mathrm{C}$ for 4 days. The culture broth (2 1) was centrifuged and the supernatant was extracted with ethyl acetate. The extract was fractionated on a silica gel column using stepwise elution with chloroform-methanol. The active material eluted with chloroform-methanol (20:1) was subjected to preparative silica gel TLC with chloroform-methanol (10:1). The active fraction was concentrated to dryness to give a colorless powder of $1(45.4 \mathrm{mg})$. From the ${ }^{1} \mathrm{H}$ and ${ }^{13} \mathrm{C}$ NMR spectra and the specific rotation $\left([\alpha]_{\mathrm{D}}^{22}\right.$ $+23.4(c 0.567, \mathrm{MeOH})$ and $[\alpha]_{\mathrm{D}}^{22}+39.0(c \quad 0.115, \mathrm{MeOH})$ in literature $^{3}$ ), 1 was identified as curromycin $A^{3,4}$ (Figure 1). The chloroform-methanol (100:1) fraction on the silica gel column contained an inactive metabolite 2 . A colorless oil of $2(12.8 \mathrm{mg})$ was obtained by preparative silica gel TLC with chloroform-methanol (10:1).

The physicochemical properties of 2 are summarized as follows: $[\alpha]_{\mathrm{D}}^{19}-13.9$ ( $c$ 0.642, MeOH); high-resolution FAB-MS m/z 199.1082 $\left([\mathrm{M}+\mathrm{H}]^{+}\right.$, calcd. for $\left.\mathrm{C}_{9} \mathrm{H}_{15} \mathrm{~N}_{2} \mathrm{O}_{3}, 199.1083\right)$; UV $(\mathrm{MeOH}) \lambda_{\max } \mathrm{nm}(\varepsilon)$ 219 (3400); IR (ATR) $\nu_{\max } 3207,1690 \mathrm{~cm}^{-1}$.

The molecular formula of 2 was established as $\mathrm{C}_{9} \mathrm{H}_{14} \mathrm{~N}_{2} \mathrm{O}_{3}$ by highresolution FAB-MS. ${ }^{13} \mathrm{C}$ and ${ }^{1} \mathrm{H}$ NMR data for 2 are summarized in Table 1. The HMQC 5 spectrum revealed three methyls, including a methoxy and an $\mathrm{N}$-methyl, an olefinic methylene, two methines and three quaternary $\mathrm{sp}^{2}$ carbons. Two amide carbonyl groups were identified based on their chemical shifts $(\delta 165.8,159.5)$ and the molecular formula. A COSY experiment displayed a spin network from $\mathrm{H}-6$ to $\mathrm{H}-10$ (Figure 2). This substructure was expanded to include the amide carbonyl (C-5) due to long-range correlations from 6- $\mathrm{H}$ and $9-\mathrm{H}$ to $\mathrm{C}-5$ in the $\mathrm{HMBC}^{6}$ spectrum (Figure 2 ). ${ }^{1} \mathrm{H}-{ }^{13} \mathrm{C}$ longrange couplings from the methoxy to C-9 and from the $\mathrm{N}$-methyl to C-2 and C-6 established their location and an amide bond between C-2 and C- 6 . The olefinic methylene protons $\left(8-\mathrm{H}_{2}\right)$ exhibited long-range correlations to $\mathrm{C}-2$, indicating the presence of an acrylamide moiety. Finally, couplings from an amide proton $(4-\mathrm{H})$ to C-2 and C-6 required a cyclic dipeptide structure consisting of dehydroalanine and $\mathrm{N}, \mathrm{O}$-dimethylthreonine (or its stereoisomer) residues.

A small coupling constant $(4.0 \mathrm{~Hz})$ between $6-\mathrm{H}$ and $9-\mathrm{H}$ arranged them in gauche conformations. The structure of 2 , including the relative stereochemistry, was determined to be cyclo(dehydroalanyl- $N$, O-dimethylthreonyl) by a NOESY experiment, which revealed NOEs between $11-\mathrm{H}_{3}$ and $7-\mathrm{H}_{3}$, between $7-\mathrm{H}_{3}$ and $10-\mathrm{H}_{3}$, and between $10-\mathrm{H}_{3}$ and 6-H, as shown in Figure 2.

The cytotoxic activity was evaluated by the 3-(4,5-dimethylthiazol2-yl)-2,5-diphenyltetrazolium bromide (MTT) method using MKN45 human gastric cancer cells ${ }^{1}$ treated with 1 or 2 for $48 \mathrm{~h}$. MTT formazan formed in the cells was dissolved in dimethyl sulfoxide (DMSO) and measured as absorbance at $540 \mathrm{~nm}$. Curromycin A (1) showed potent cytotoxicity against MKN45 cells in a nutrient-deprived medium (Earle's salts solution supplemented with $10 \%$ fetal bovine serum), with an $\mathrm{IC}_{50}$ of $15 \mathrm{ng} \mathrm{ml}^{-1}$. The growth of MKN45 cells in a normal medium (Dulbecco's modified Eagle's medium with 10\% fetal bovine serum) was inhibited $\sim 50 \%$ by 1 at the range of $20-20$ $000 \mathrm{ng} \mathrm{ml}^{-1}$, although no cell death was observed. Anticancer agents such as doxorubicin displayed reverse selectivity in this assay. The $\mathrm{IC}_{50}$ values of doxorubicin were $1.1 \mu \mathrm{g} \mathrm{ml}^{-1}$ in a normal medium and $>20 \mu \mathrm{g} \mathrm{ml}^{-1}$ in a nutrient-deprived medium. No activity was observed on MKN45 cells treated with 2 at $<10 \mu \mathrm{g} \mathrm{ml}^{-1}$.

${ }^{1}$ Department of Medicinal and Life Science, Faculty of Pharmaceutical Sciences, Tokyo University of Science, Chiba, Japan and ${ }^{2}$ Biological Information Research Center, National Institute of Advanced Industrial Science and Technology, Tokyo, Japan

Correspondence: Professor Y Hayakawa, Department of Medicinal and Life Science, Faculty of Pharmaceutical Sciences, Tokyo University of Science, 2641 Yamazaki, Noda, Chiba 278-8510, Japan.

E-mail: hykw@rs.noda.tus.ac.jp

Received 11 July 2015; revised 18 September 2015; accepted 9 October 2015; published online 25 November 2015 
<smiles>COCC1OC(=O)C12C(C(CC(C)C(O)/C=C/C=C/CNC(=O)C(C)(C)C(O)/C(C)=C\C=C/C=C/Cc1cnc(C)o1)OC)C(C)C(=O)N2C</smiles>

Curromycin A (1)<smiles>C=C1NC(=O)C([C@H](C)OC)N(C)C1=O</smiles>

2

Figure 1 Structures of metabolites from Streptomyces sp. RAI364.

Table $1{ }^{13} \mathrm{C}$ and ${ }^{1} \mathrm{H}$ NMR data for 2 in $\mathrm{CDCl}_{3}$

\begin{tabular}{lll}
\hline No. & $\delta C$ & $\delta_{H}(J=H z)$ \\
\hline 2 & $159.5 \mathrm{~s}$ & \\
3 & $133.6 \mathrm{~s}$ & \\
4 & & $8.88 \mathrm{~s}$ \\
5 & $165.8 \mathrm{~s}$ & \\
6 & $68.0 \mathrm{~d}$ & $3.88 \mathrm{~d}(4.0)$ \\
7 & $36.4 \mathrm{q}$ & $3.093 \mathrm{H} \mathrm{s}$ \\
8 & $102.4 \mathrm{t}$ & $5.57 \mathrm{~s}, 4.84 \mathrm{~s}$ \\
9 & $79.0 \mathrm{~d}$ & $3.69 \mathrm{dq}(4.0,6.5)$ \\
10 & $16.6 \mathrm{q}$ & $1.253 \mathrm{H} \mathrm{d}(6.5)$ \\
11 & $57.1 \mathrm{q}$ & $3.313 \mathrm{H} \mathrm{s}$ \\
\hline
\end{tabular}

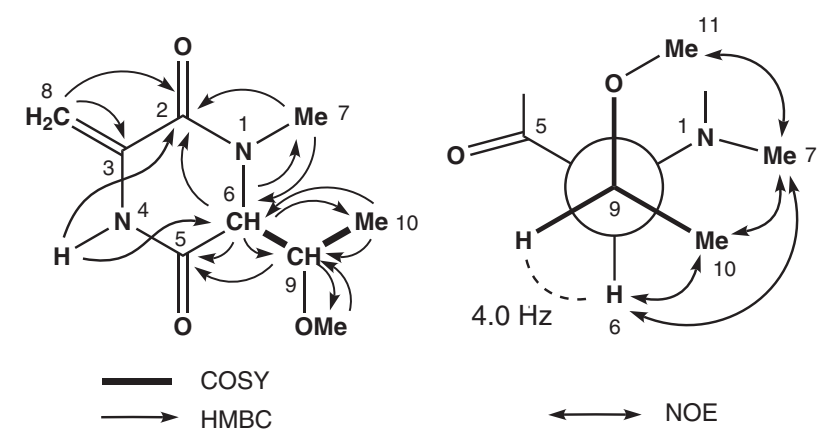

Figure 2 NMR analysis of 2 .

The molecular chaperone GRP78 is involved in the resistance to nutrient-deprivation stress. $^{7-9}$ The effect of $\mathbf{1}$ on GRP78 gene expression was investigated by the luciferase reporter assay using HT1080 human fibrosarcoma cells transformed with the luciferase gene under the control of the GRP78 promoter (HT1080 G-L). ${ }^{10}$ Curromycin A (1) dose-dependently inhibited the luciferase expression in the presence of $10 \mathrm{~mm}$ of 2-deoxyglucose with an $\mathrm{IC}_{50}$ of $4.3 \mathrm{ng} \mathrm{ml}^{-1}$ (Figure 3). The antibacterial and cytotoxic activities of 1 have been reported, ${ }^{3,4}$ although the mechanisms of action are unknown. Further biological studies are now under way.

\section{CONFLICT OF INTEREST}

The authors declare no conflict of interest.

\section{ACKNOWLEDGEMENTS}

This work was supported in part by a Grant-in-Aid for Challenging Exploratory Research (25560407), Japan Society for the Promotion of

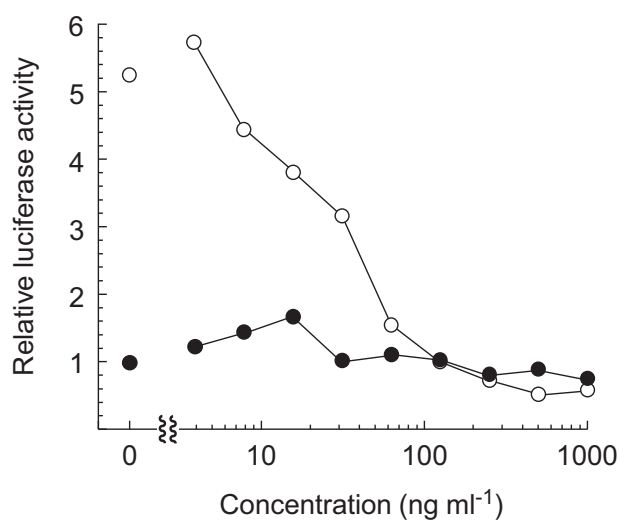

Figure 3 Effect of curromycin A (1) on the luciferase expression in HT1080 G-L cells. HT1080 G-L cells were treated with 1 in the presence $(O)$ or absence (O) of 2-deoxyglucose $(10 \mathrm{~mm})$ for $18 \mathrm{~h}$ at $37^{\circ} \mathrm{C}$. The relative luciferase activity compared with non-treated control was measured with a luminometer.

Science (JSPS). We thank F Hasegawa, Tokyo University of Science, for assistance with MS.

1 Izuishi, K., Kato, K., Ogura, T., Kinoshita, T. \& Esumi, H. Remarkable tolerance of tumor cells to nutrient deprivation: possible new biochemical target for cancer therapy. Cancer Res. 60, 6201-6207 (2000).

2 Weisburg, W. G., Barns, S. M., Pelletier, D. A. \& Lane, D. J. 16S ribosomal DNA amplification for phylogenetic study. J. Bacteriol. 173, 697-703 (1991).

3 Ogura, M. et al. Structure of a new antibiotic curromycin A produced by a genetically modified strain of Streptomyces hygroscopicus, a polyether antibiotic producing organism. J. Antibiot. 38, 669-673 (1985).

4 Ikeda, Y. et al. New triene- $\beta$-lactone antibiotics, triedimycins A and B. J. Antibiot. 44, 453-455 (1991).

5 Summers, M. F., Marzilli, L. G. \& Bax, A. Complete ${ }^{1} \mathrm{H}$ and ${ }^{13} \mathrm{C}$ assignments of coenzyme $\mathrm{B}_{12}$ through the use of new two-dimensional NMR experiments. J. Am. Chem. Soc. 108, 4285-4294 (1986).

6 Bax, A. \& Summers, M. F. ${ }^{1} \mathrm{H}$ and ${ }^{13} \mathrm{C}$ assignments from sensitivity enhanced detection of heteronuclear multiple-bond connectivity by multiple quantum NMR. J. Am. Chem. Soc. 108, 2093-2094 (1986).

7 Munro, S. \& Pelham, H. R. An Hsp70-like protein in the ER: identity with the 78 kd glucose-regulated protein and immunoglobulin heavy chain binding protein. Cell 46, 291-300 (1986).

8 Fernandez, P. M. et al. Overexpression of the glucose-regulated stress gene GRP78 in malignant but not benign human breast lesions. Breast Cancer Res. Treat. 59, 15-26 (2000).

9 Yoshida, H., Haze, K., Yanagi, H., Yura, T. \& Mori, K. Identification of the cis-acting endoplasmic reticulum stress response element responsible for transcriptional induction of mammalian glucose-regulated proteins. Involvement of basic leucine zipper transcription factors. J. Biol. Chem. 273, 33741-33749 (1998); Erratum in: J. Biol. Chem. 274, 2592 (1999).

10 Park, H. R. et al. Effect on tumor cells of blocking survival response to glucose deprivation. J. Nat/ Cancer Inst. 96, 1300-1310 (2004). 